Barbara Kudra*

\title{
O komunikacji społecznej
}

„[...] najbardziej trafnym wyróżnikiem człowieka wydaje się określenie homo communicans, gdyż właśnie umiejętność skutecznego porozumiewania się z innymi przyczyniła się do rozwoju specyficznie ludzkiej kultury" (Kaczmarek 2009: 11). Wypowiedź ta podkreśla ludzki i zarazem społeczny wymiar procesu komunikacji.

Literatura naukowa na temat komunikacji społecznej jest bardzo bogata. Dlatego w artykule odniosę się tylko do wybranych, powszechnie uznanych ujęć komunikacji społecznej oraz jej podstawowych wyróżników. Moim celem jest bowiem wskazanie najważniejszych zagadnień (problemów) dotyczących komunikacji społecznej, a nie próba ogarnięcia czy wyczerpania wszystkich treści z nią związanych.

Komunikowanie może być interpretowane w różnym kontekście: lingwistycznym, instrumentalnym, interpersonalnym oraz kulturowym (Nęcki 2003: 9).

W kontekście lingrwistycznym kładzie się nacisk na wszystkie wypowiedzi poprzedzające daną kwestię; w instrumentalnym ważny jest typ zadania, sytuacji, w jakiej odbywa się komunikacja, liczy się też cel i funkcja wypowiedzi; w kontekście interpersonalnym istotne jest kto z kim rozmawia, czyli rodzaj relacji między rozmówcami, a kontekst kulturowy skłania ku zwróceniu szczególnej uwagi na cechy wypowiedzi charakterystyczne dla danego narodu, kraju czy grupy. Wynika z tego, że komunikowanie społeczne jest procesem złożonym, wieloaspektowym. Dlatego też jego analizy wymagają optymalnego interdyscyplinarnego/transdyscyplinarnego podejścia, tj. psychologicznego, lingwistycznego, socjologicznego, pedagogicznego itp. Nauka o komunikowaniu (komunikologia), która zajmuje się zagadnieniami związanymi

" Prof. nadzw. dr hab. Barbara Kudra - Uniwersytet Łódzki, Wydział Filologiczny, Katedra Współczesnego Języka Polskiego, al. Kościuszki 65, 90-514 Łódź. 
z komunikacją, jest nauką z pogranicza różnych dyscyplin. Interdyscyplinarność komunikologii na poniższym wykresie dokładnie przedstawiła Bogusława Dobek-Ostrowska (2007: 23).

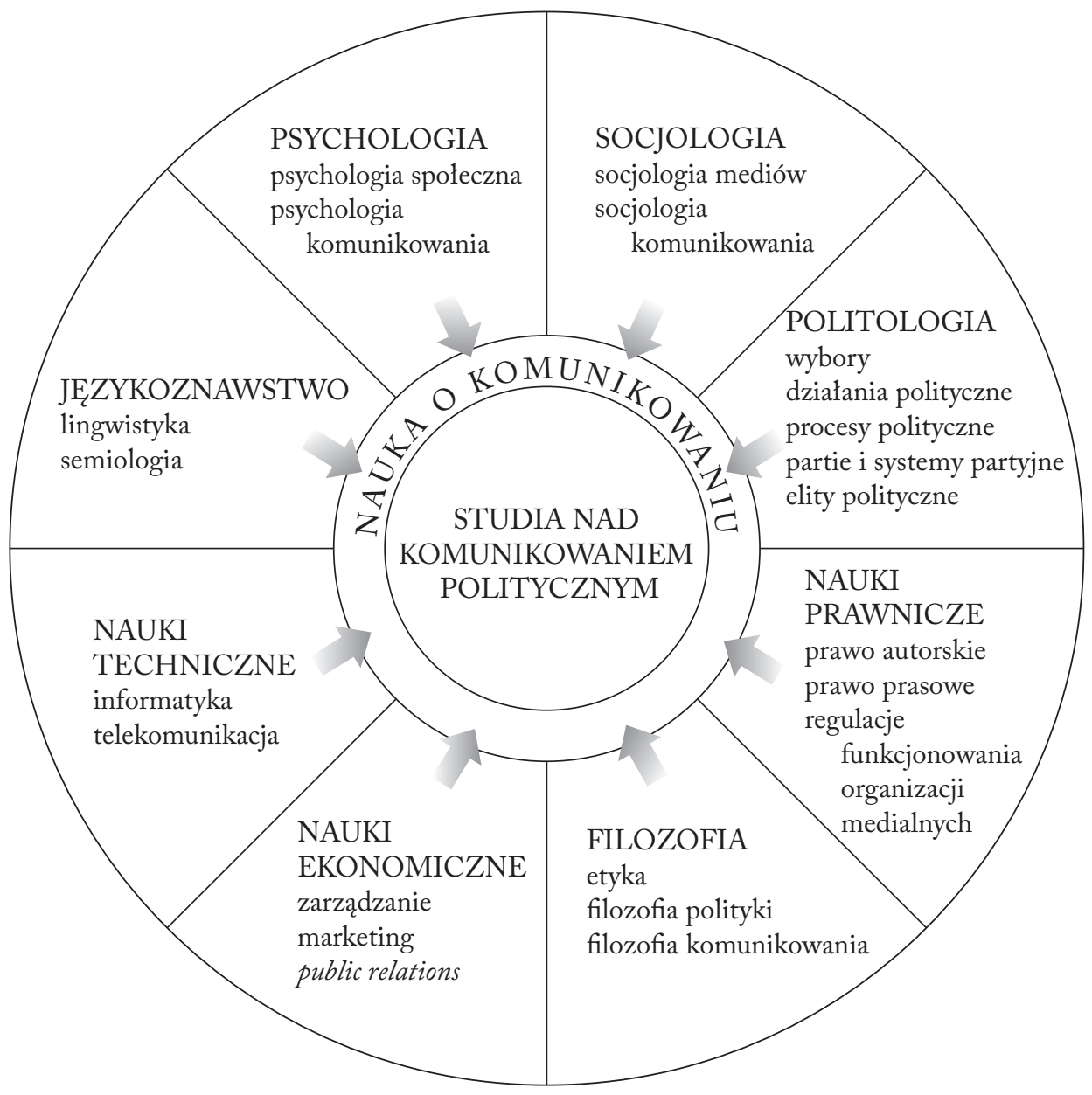

Schemat 1. Interdyscyplinarność nauki o komunikowaniu Źródło: Dobek-Ostrowska 2007: 23

Problematyka badań w nauce o komunikowaniu obejmuje następujące zagadnienia: nadawca, intencja (studia nad perswazją, propagandą, strategiami komunikacyjnymi), przekaz (analiza empiryczna i semiologiczna różnych tekstów), kodowanie (kody werbalne i niewerbalne, zawartość przekazu), kanal (m.in. nowe technologie, środki w komunikowaniu interpersonalnym, grupowym, masowym), działanie komunikacyjne (dynamika interakcji 
w strukturach organizacyjnych), szum (zakłócenia psychologiczne i fizyczne), odbiorca (m.in. badanie publiczności), dekodowanie (studia nad percepcją), interpretacja (rozumienie tekstu, sens, znaczenie), efekt (społeczny, kulturalny, reklama, opinie, wartości, socjalizacja), sprzężenie zwrotne (komunikowanie w organizacjach, komunikowanie interpersonalne) (Dobek-Ostrowska 2007: 24).

W naukach humanistycznych często podkreśla się (i uznaje) rolę psychologii społecznej w komunikowaniu. W tej koncepcji komunikacja społeczna jest zachowaniem, które można obserwować; jest procesem wymiany interpersonalnej regulującej właściwe stosunki między ludźmi (Nęcki 1992: 29).

Zanim rozważymy istotę procesu komunikacji społecznej, przyjrzyjmy się podobieństwom i różnicom w sposobie definiowania pojęcia komunikacja/komunikowanie (się).

\section{KoMUNIKACJA, KOMUNIKOWANIE (SIĘ) - UJĘCIA DEFINICYJNE}

Według Walerego Pisarka komunikowaniem nazywamy „przekazywanie treści psychicznej, i to zarówno treści intelektualnej, jak i emocjonalnej, a więc tego, co się myśli lub tego, co się czuje, przez osobnika (lub osobników) A osobnikowi (lub osobnikom) B" (Pisarek 2008: 17).

Bogusława Dobek-Ostrowska rozszerza definicję W. Pisarka. Definiuje komunikowanie jako „proces porozumiewania się jednostek, grup lub instytucji. Jego celem jest wymiana myśli, dzielenie się wiedzą, informacjami i ideami. Proces ten odbywa się na różnych poziomach, przy użyciu zróżnicowanych środków i wywołuje określone skutki” (Dobek-Ostrowska 2002: 13). Co ważne, autorka przypisuje komunikowaniu kilka zasadniczych cech (tamże: 14-15). Jest ono procesem społecznym (przebiega zawsze na gruncie relacji międzyludzkich i w określonym kontekście społecznym), jest determinowane przez liczbę i charakter uczestników procesu (np. kontekst interpersonalny, grupowy, instytucjonalny, publiczny, masowy, międzykulturowy). Jest też procesem kreatywnym, ponieważ polega na budowaniu nowych pojęć, nowej wiedzy o świecie. Komunikowanie ma charakter dynamiczny, polega bowiem na ciągłej interpretacji informacji, które do nas docierają. Komunikowanie jest również procesem interakcyjnym, bo między jego uczestnikami wytwarzają się określone stosunki.

W słownikach języka polskiego znajdziemy definicje czasowników komunikować i komunikować się. I tak: Inny stownikjęzyka polskiego PWN (Bańko [red.] 2000: 658) notuje trzy rozumienia: 
- jeśli ktoś komunikuje się z kimś, to wymienia z nim jakieś informacje, np. w rozmowie lub listownie; mówimy też, że dwie osoby się komunikują;

- jeśli komunikujemy komuś coś, to zawiadamiamy go o tym;

- jeśli dwie części jakiegoś systemu komunikują się, to istnieje pomiędzy nimi przepływ informacji, energii, materii itd. Mówimy też, że jedna część jakiegoś systemu komunikuje się z drugą.

Uniwersalny stownik jezzyka polskiego PWN (Dubisz [red.] 2008: 192) podaje następujące definicje: komunikować - 'podawać coś do wiadomości, przekazywać jakąś informację, zawiadamiać o czymś; komunikować się 'utrzymywać z kimś kontakt, porozumiewać sięe', a drugie znaczenie 'mieć połączenie, łączyć się’.

Różnicę w znaczeniach obu czasowników komunikować i komunikować się trafnie ujęła Urszula Żydek-Bednarczuk:

Komunikowanie się to proces, w którym interlokutorzy zamieniają się rolami i wspólnie uczestniczą w przekazywaniu informacji, są ze sobą w interakcji. Proces ten jest dwukierunkowy i wymaga bądź styczności fizycznej nadawcy i odbiorcy, bądź medium, które takie sprzężenie zwrotne umożliwia [...]. Natomiast komunikowanie (bez zaimka zwrotnego) dokonuje się dzięki mediom i środkom transmisji informacji. Jako proces charakteryzuje się jednokierunkowością. Ważny jest nadawca - odbiorca zaś „słucha” (Żydek-Bednarczuk 2005: 10).

Marian Bugajski akcentuje w definicji komunikowania łaciński źródłosłów czasownika communico - 'uczynić wspólnym, połączyć, udzielić wiadomości'. „Communio to 'uczestnictwo, wspólność'. To pozwala sądzić, że komunikacja to nie tylko porozumiewanie się, ale także stanowienie wspólnoty" - podkreśla Bugajski (2006: 436). Co do rzeczowników komunikacja i komunikowanie, to zwykle używa się ich wymiennie, choć z semantycznego punktu widzenia w leksemie komunikowanie akcent położony jest na procesualność, a w komunikacji na efekt, wytwór/produkt.

\section{MODELE (SCHEMATY) KOMUNIKACJI JĘZYKOWEJ}

W objaśnianiu złożonego procesu komunikacji pomocne są abstrakcyjne, uproszczone modele, przybliżające i obrazujące ten skomplikowany proces. Trzeba od razu podkreślić, że język odgrywa w porozumiewaniu się najważniejszą rolę. Dlatego najstarszy model, Karla Bühlera, to model komunikacji językowej. Badacz wyróżnił w nim nadawcę, tekst i odbiorcę. Najbardziej znanym modelem wśród lingwistów jest model Romana Jakobsona, mimo że dotyczył on tekstu poetyckiego. Model ten zawiera więcej elementów składowych niż Bühlerowski. Według R. Jakobsona: 
Nadawca kieruje komunikat do odbiorcy. Aby komunikat był efektywny, musi on odnosić się do kontekstu (czyli musi coś oznaczać), kontekstu uchwytnego dla odbiorcy i albo zwerbalizowanego, albo dającego się zwerbalizować; dalej, konieczny jest kod, w pełni lub przynajmniej w części wspólny dla nadawcy i odbiorcy [...]; na koniec musi istnieć kontakt - fizyczny kanał i psychiczny związek między nadawcą i odbiorcą, umożliwiający im obu nawiązanie i kontynuowanie komunikacji (Jakobson 1989: 81).

Tak pojęty akt komunikacji został zobrazowany następującym schematem:

Nadawca $\frac{\begin{array}{c}\text { Kontekst } \\ \text { Komunikat }\end{array}}{\begin{array}{c}\text { Kontakt } \\ \text { Kod }\end{array}}$ Odbiorca

Kolejne schematy/modele jeszcze bardziej rozszerzyły Jakobsonowską propozycję o takie elementy, jak: kanał, czyli droga przekazu; szumy, które uniemożliwiają prawidłową komunikację lub ją blokują; sprzężenie zwrotne, tj. reakcja odbiorcy (w modelu R. Jakobsona odbiorca jest pasywny).

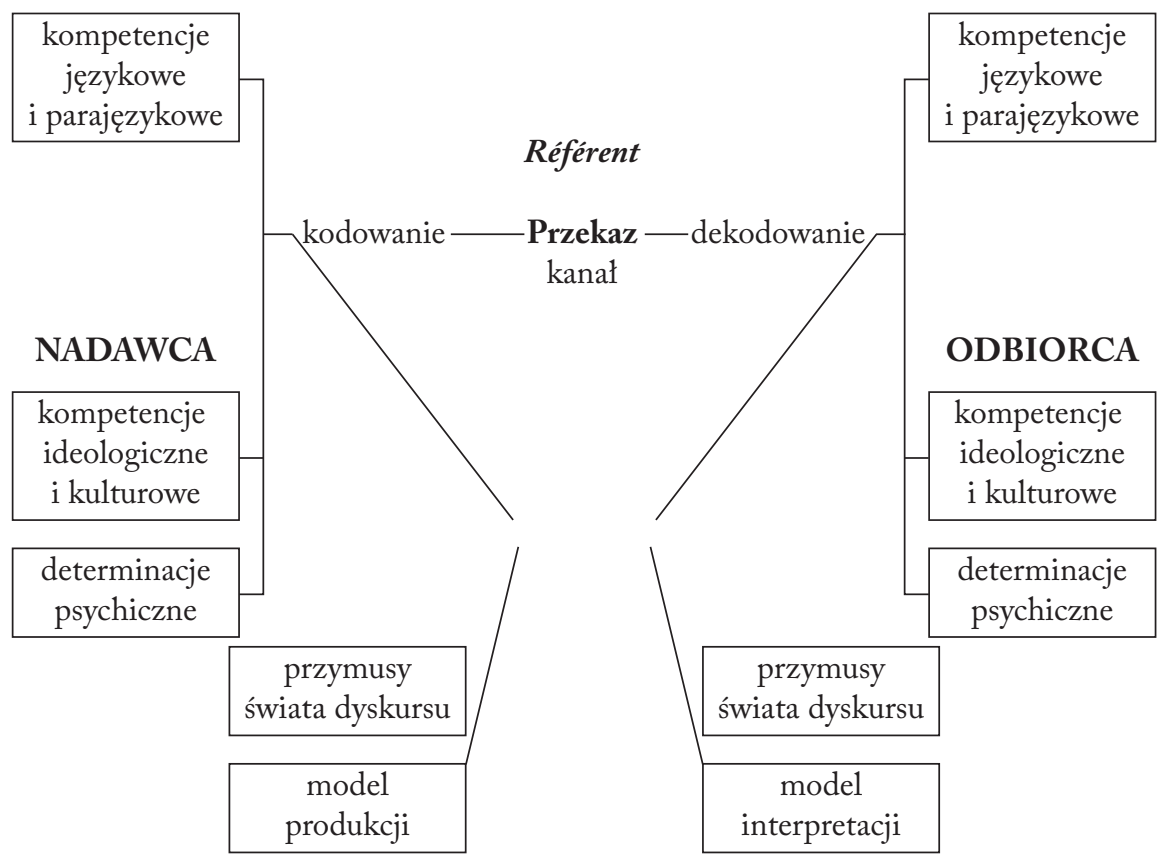

Schemat 2. Schemat komunikacji C. Kerbrat-Orecchioni Źródło: Kita 1998: 23 
$\mathrm{Na}$ przykład w modelu Catherine Kerbrat-Orecchioni (schemat 2) nadawca i odbiorca posiadają kompetencje językowe i parajęzykowe, kompetencje ideologiczne i kulturowe oraz uwarunkowania psychiczne. Widoczne są też w tym modelu dwa poziomy komunikacji: na poziomie nadawczym komunikat jest tworzony i nadawany, a na poziomie odbioru komunikat jest dekodowany i interpretowany. Można też zauważyć, że i nadawca, i odbiorca mówią „różnymi” językami, bo mogą posiadać różne kompetencje językowe i kulturowe.

Urszula Żydek-Bednarczuk, proponując własny schemat komunikacji (2005: 25-29), rozszerza go o elementy związane z kontekstem i sytuacją, a przede wszystkim podkreśla interakcję między nadawcą i odbiorcą. Pisze:

Interakcja warunkuje powstanie tekstu. Jest ona tym elementem w komunikacji, który może dotyczyć języka mówionego - powoduje wtedy wymianę ról nadawczo-odbiorczych. Może też być efektem powstania tekstu pisanego - np. recenzji, referatu, gdzie interakcja nie zawsze związana jest ze zmianą roli nadawczo-odbiorczej. Musi ona uwzględniać następujące kryteria: uczestnicy, temat, forma efektu interakcji czyli ramę układu interakcyjnego JA, TY, TU, TERAZ. O interakcji nie możemy mówić jako o zjawisku jednostkowym [...]. Skłonni jesteśmy uznać interakcję za zespół działań językowych prowadzonych zarówno z uwzględnieniem wzoru charakterystycznego dla danej instytucji, grupy społecznej, jak i indywidualnych wymian, w których istnieje powtarzalność zachowań oraz kreatywność (Żydek-Bednarczuk 2005: 24).

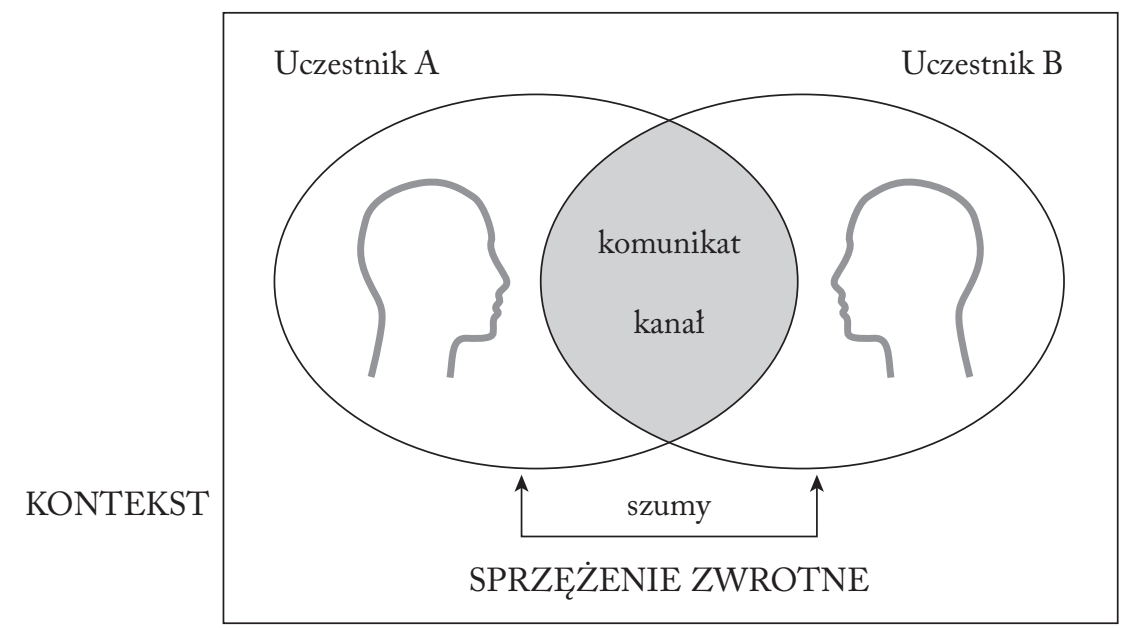

Schemat 3. Elementy procesu komunikowania według B. Dobek-Ostrowskiej Źródło: Dobek-Ostrowska 2007:64 


\title{
Stanisław Grabias natomiast nakłada na interakcję szereg ustalonych
} reguł, znanych uczestnikom aktu komunikacyjnego (1994: 219). Stwierdza:

\begin{abstract}
Aby wypowiedź stała się komunikatem, nadawcę i odbiorcę musi łączyć psychiczna gotowość do podjęcia interakcji (chęć rozmowy i wysiłek włożony w odkrywanie intencji nadawcy) oraz tożsamość kulturowa wyznaczona wspólnym systemem wartości, pozwalających ujmować rzeczywistość w podobnych kategoriach intelektualnych i w miarę podobnych kategoriach emocjonalnych (Grabias 1994: 232).
\end{abstract}

Niezależnie od różnych modelowych propozycji każdy proces komunikacji składa się z szeregu ściśle ze sobą powiązanych elementów, które „decydują o dynamicznym i transakcyjnym charakterze komunikatu. Do stałych elementów procesu zalicza się kontekst, uczestników, przekaz/komunikat, kanal, szumy i sprzężenie zwrotne" (Dobek-Ostrowska 2007: 64) - schemat 3.

$\mathrm{Z}$ przeglądu schematycznych ujęć komunikowania widać, w jakim kierunku zmierzają $\mathrm{w}$ nich zmiany. Zestawienia schematów komunikacji dokonała U. Żydek-Bednarczuk (2005: 21), akcentując modyfikacje w ich obrębie, które polegają na:

- rozszerzeniu części związanej z sytuacją i kontekstem (wprowadzenie relewancji i referencji);

- wykorzystaniu w schemacie uwarunkowań społeczno-kulturowych, które wpływają na produkcję tekstu;

- wprowadzeniu pojęcia dyskursu obok tekstu;

- uzupełnieniu kompetencji komunikacyjnej o przymus dyskursów i gatunki mowy;

- rozszerzeniu pojęć nadawcy i odbiorcy (od obu wymaga się określonej wiedzy o świecie, kompetencji językowej i pozajęzykowej oraz przypisuje się im intencję i recepcję);

- zastąpieniu kodu przez język (zachowano pojęcie kodowania i dekodowania tekstu, przekazu).

W schematach komunikacji pojawiają się pojęcia m.in. dyskursu i interakcji. Jaka jest ich relacja w stosunku do pojęcia komunikacji? Interakcja warunkuje komunikację. By doszło do komunikacji, musi istnieć wzajemne oddziaływanie nadawcy i odbiorcy. Dyskurs natomiast, rozumiany jako zdarzenie komunikacyjne, jest jedną z form, technik komunikacji, ale też jej produktem.

Podsumować można krótko wszystkie zmiany w schematach/modelach komunikacji językowej następującą wypowiedzią:

Nastawienie interakcyjne $\mathrm{w}$ komunikacji polega więc na rozpoznawaniu komunikacyjnych możliwości odbiorcy. Najważniejsze staje się wejście w aktualizowany kontekst funkcjonalny wypowiedzi - do kogo, w jakim celu, w jakiej sytuacji - nie zaś pozostawanie w niezmiennym, indywidualnym kontekście własnych możliwości 
nadawczych. Tworząc komunikat, winniśmy go tworzyć ze względu na jego aktualnego odbiorcę, nie zaś wyłącznie ze względu na własną indywidualną ekspresję (Skudrzykowa 2001: 335).

M. Bugajski dodaje jeszcze, powołując się na W. J. Onga (1992: 230), że „W rzeczywistej komunikacji ludzkiej nadawca musi nie tylko przyjąć pozycję nadawcy, lecz także pozycję odbiorcy, zanim może cokolwiek przesłać”. Podkreśla również, że „gdy nie ma komunikacji bezpośredniej z fizyczną obecnością odbiorcy, to nadawca jako odbiorców «wyczarowuje osoby fikcyjne»" (Bugajski 2006: 443). Tak się dzieje m.in. w komunikacji masowej, medialnej, gdy nadawca „musi sobie wyobrazić tzw. odbiorcę masowego (odbiorcę zbiorowego, zbiorowość odbiorców) i powinien mieć pewność, że do niego dotarł i został właściwie zrozumiany" (tamże, s. 443). To spostrzeżenie M. Bugajskiego prowadzi nas do pojęcia komunikacji medialnej, która jest zarazem komunikacją masową.

Zanim jednak przejdziemy do medialnego i innych typów komunikowania, warto przyjrzeć się zestawieniu różnych ujęć komunikacji, które zawarte są w książce pt. Komunikacja między ludźmi. Motywacja, wiedza i umiejętności (Morreale, Spitzberg, Barge 2008: 3-40). Są to następujące rozumienia komunikacji:

- komunikacja jako proces organizowania wiadomości w celu stworzenia znaczenia, przy czym wiadomości mogą być wytwarzane w toku interakcji werbalnie lub niewerbalnie - poprzez dźwięki, działania i gesty; organizowanie należy rozumieć jako zarządzanie lub kierowanie ludźmi lub materiałem, a znaczenie odnosi się do interpretacji wiadomości;

- komunikacja jako transfer informacji. Model takiej komunikacji obejmuje: nadawcę, odbiorcę, kanał jako środek przekazu wiadomości, wiadomość, kodowanie, dekodowanie, szumy (zakłócenia), które mogą wystąpić na poziomie wiadomości, kodowania i dekodowania;

- komunikacja jako uzgadnianie znaczenia (zrozumienie wiadomości przez odbiorcę). Mamy wtedy do czynienia z interakcyjnym modelem komunikacji, kodowanie i dekodowanie wraz z szumami dotyczy zarówno nadawcy, jak i odbiorcy;

- komunikacja jako transakcyjny model. Ludzie są tu równoczesnymi nadawcami i odbiorcami wiadomości, np. w trakcie komunikowania odbiorca wysyła nadawcy wiadomości niewerbalne (gestykulacją, wzrokiem itp.);

- komunikacja jako perswazja. Nadawca ma na celu zmianę postaw, wartości, działań odbiorcy lub ich wzmocnienie;

- komunikacja jako tworzenie społeczności.

Wymienione ujęcia komunikowania wiążą się też z jego funkcjami. Są nimi, według Bogusławy Dobek-Ostrowskiej (2007: 68-69): funkcja informacyjna, edukacyjna, identyfikacji osobistej, integracyjna, mobilizacyjna, rozrywkowa. 
Walery Pisarek (2008: 174-177) krytycznie ustosunkowuje się do zagadnienia klasyfikacji, typologii i funkcji procesów komunikowania. Jest zwolennikiem przedstawiania raczej typologii otwartej, wieloaspektowej, niż „modelowej doskonałej klasyfikacji”. W związku z tym wyodrębnia osiem kryteriów podziału, którym podporządkowuje poszczególne funkcje komunikowania. Są to m.in. takie kryteria, jak: sposobu komunikowania (funkcja powiadamiająca/informacyjna, funkcja komentująca), skutku komunikowania (funkcje: socjalizująca, integracyjna, innowacyjna, inspirująca, kryminogenna itd.), zakresu/dziedziny komunikowania (funkcje: polityczna, gospodarcza, oświatowa, kulturalna, administracyjna, prawna, językowa, estetyczna itd.), systemu wartości (funkcja pożądana, funkcja niepożądana/dysfunkcja), świadomości nadawcy (funkcja zamierzona, funkcja niezamierzona).

\section{TYPOLOGIE PROCESÓW KOMUNIKOWANIA}

Klasyfikacje procesów komunikowania otwiera schemat Denisa McQuaila, który przedstawia podział procesu komunikowania ze względu na zasięg uczestników, wyróżniając następujące poziomy komunikowania: intrapersonalne, interpersonalne, grupowe, między grupami, organizacyjne (instytucjonalne), masowe (schemat 4). Piramida McQuaila pokazuje jednocześnie, który z poziomów jest najszerszy, obejmujący największy zasięg uczestników komunikacji.

Bogusława Dobek-Ostrowska (2007) przedstawia także inne klasyfikacje/typologie. Na przykład ze względu na kanał porozumiewania się wyróżnia komunikowanie:

- interpersonalne (bezpośrednie);

- masowe (pośrednie);

- interpersonalne sieciowe (pośrednie). Dodajmy, że głównymi kanałami w komunikowaniu interpersonalnym są kanały formalne (struktury instytucjonalne) oraz nieformalne (duża wymienność ról nadawców i odbiorców).

Ze względu na stosowane znaki i kody komunikowanie dzieli się na:

- werbalne (cyfrowe): forma ustna, forma pisemna;

- niewerbalne (analogowe): kinezjetyka (związana $z$ ekspresją twarzy i mową ciała), parajęzyk (cechy wokalne: ton, barwa, wysokość, natężenie głosu, tempo mówienia), autoprezentacja (wygląd fizyczny, ubranie, fryzura, makijaż, budowa ciała), haptyka (dotyk, uścisk dłoni, pocałunki, poklepywanie), proksemika (relacje przestrzenne, dystans), chronemika (czas), elementy otoczenia (temperatura, oświetlenie, hałas). 


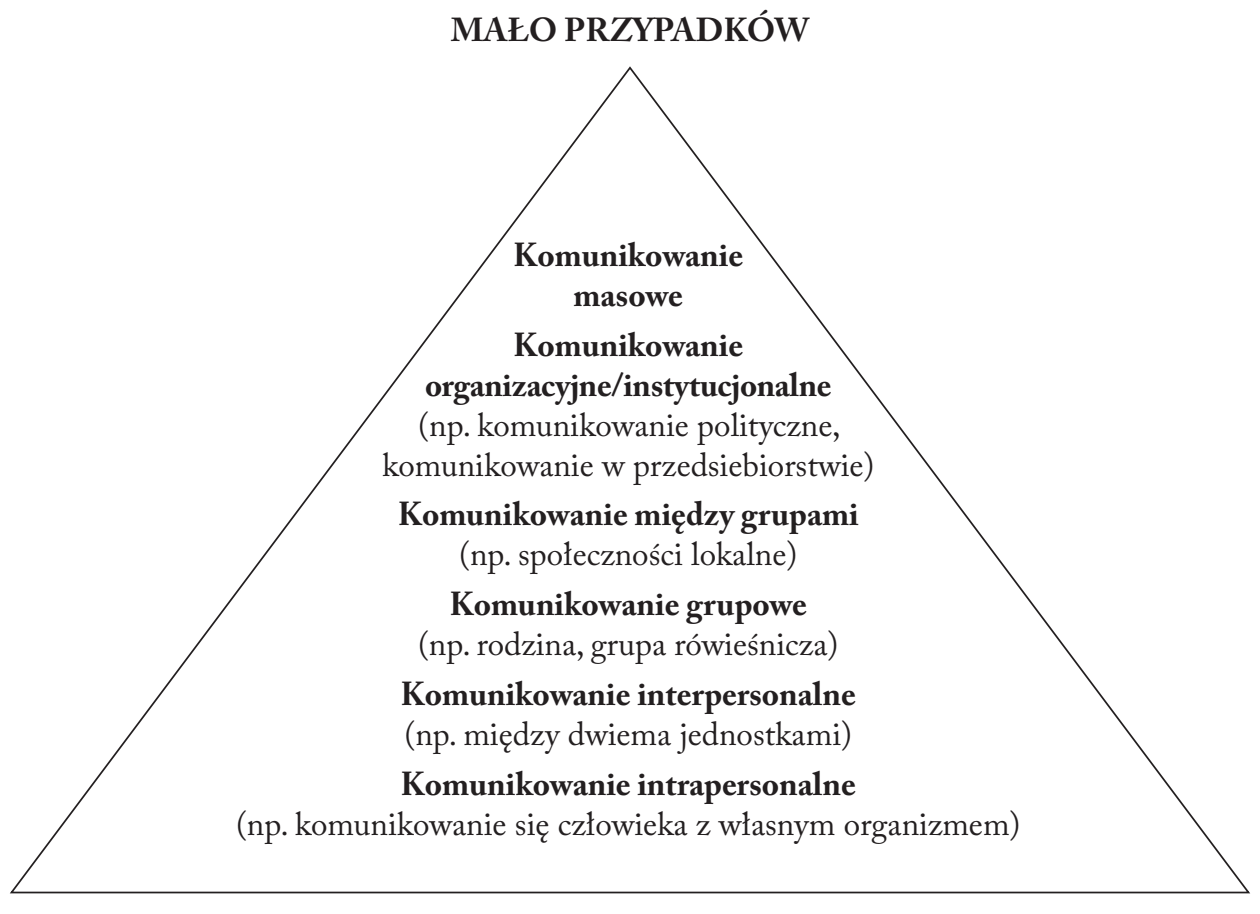

\section{DUŻO PRZYPADKÓW}

Schemat 4. Piramida McQuaila - poziomy komunikowania Źródło: Dobek-Ostrowska 2007:71

Komunikowanie niewerbalne pełni następujące funkcje: zastępowania, uzupełnienia, ekspozycji (pozy ukazujące uczucia, emocje), regulacji (kontrola), moderujące (tzw. adaptatery, np. do łagodzenia napięć) (tamże: 81-82).

Ważny jest też podział procesu komunikowania ze względu na cel przekazu. Wyróżnia się tu komunikowanie informacyjne oraz perswazyjne (tamże: 83-87).

W nawiązaniu do ostatniego podziału proponowałabym jeszcze jeden ze względu na intencję nadawcy i jego dominującą rolę (asymetryczność ról nadawcy i odbiorcy, narzucanie swej woli odbiorcy) warto, moim zdaniem, wyróżnić komunikację apodyktyczną, którą można byłoby przeciwstawić komunikacji deliberatywnej (symetria ról nadawcy i odbiorcy, partnerstwo i dążenie do kompromisowego rozwiązania).

Pewne cechy komunikacji deliberatywnej odnajdujemy w wyróżnionej przez Stephena Coveya (Stewart [red.] 2007: 66-68) komunikacji synergicznej, która jest, według autora, m.in. efektywna, zaangażowana, kreatywna, skuteczna, uwzględniająca aspekty zaufania, szacunku, empatii i kompromisu. 
Marian Bugajski natomiast dzieli komunikację na dominującą (komunikacja oficjalna, upowszechniana przez środki masowego przekazu; o pośrednim, zbiorowym, jednokierunkowym kontakcie $\mathrm{z}$ uprzywilejowaną pozycją nadawcy i uwydatniona perswazyjną funkcją języka) i alternatywną (komunikacja wspólnot komunikatywnych, uczestnicząca, z aktywnymi, twórczymi, upodmiotowionymi uczestnikami) oraz odpowiednio oficjalną i nieoficjalną (Bugajski 2006: 419).

Ciekawie i inaczej o typologii komunikacji wypowiada się Michael Fleischer (2012). Przywołując przykłady rodzajów komunikacji za różnymi badaczami, zwraca uwagę na to, że nie powinno się mylić tematów komunikacji, które mogą być najróżniejsze, z typami komunikacji. Badacz podejmuje próbę strukturalnej i funkcjonalnej typologizacji komunikacji, przyjmując następujące założenie: „przedmiotem badań komunikacji społecznej jest tylko i wyłącznie komunikacja face-to-face, czyli, by tak rzec, żywa komunikacja, odbywająca się w sytuacji fizycznej obecności aktantów danych aktów komunikacji. Wszystkie inne formy są, tak czy inaczej, limitowanymi komunikacjami lub notacjami takich limitowanych komunikacji” (Fleischer 2012: 9). Zgodnie z przyjętym założeniem badacz wyróżnia 10 typów komunikacji face-to-face, czyli bezpośredniej. Warto je tu przywołać:

- komunikacja frazeologiczna - skonwencjonalizowana, stereotypowa. W jej ramach transportuje się znaczenia już wynegocjowane (interlokutorzy jedynie utwierdzają się w określonych mniemaniach). „Komunikacja frazeologiczna jak ognia unika wątpliwości i niepewności, wielości poglądów i relatywizmu, gdyż te niszczą jej strukturę i niwelują funkcję" (tamże: 38-39);

- komunikacja tautologiczna - polega na współdziałaniu interlokutorów, którzy „podrzucają sobie funkcjonalnie identyczne (lecz strukturalnie różne) wypowiedzi, przez co dochodzi do czegoś, co można by nazwać komunikacyjnym kręceniem się w kółko" (tamże: 43);

- komunikacja termostatowa - przebiega „na zasadzie działania termostatu, czyli na bezpośrednim następstwie akcji i reakcji oraz stałej wymianie wypowiedzi [...]. Mamy zatem do czynienia z pętlą feedbacku [...], komunikacja kręci się w kółko [...] nie ma początku ani końca" (tamże: 48), oparta jest na schemacie pytań i odpowiedzi;

- komunikacja diagnostyczna - „wypowiedź czy akt komunikacji stanowią swego rodzaju pretekst do czegoś innego, z komunikacją niemającego już nic lub zbyt wiele wspólnego [...]. Komunikacje diagnostyczne to wszelkie komunikacje, w których nie chodzi o to, co się mówi, lecz o to, jak się mówi, czy generalnie - komunikuje" (tamże: 52-53);

- komunikacja działaniowa - „chodzi wyłącznie o produkcję jako element działania w danej sytuacji społecznej w celu podtrzymania tej sytuacji 
przy pomocy komunikacji, a więc kiedy zaprzestanie produkcji wypowiedzi lub brak jej produkcji zakłóciłby lub zlikwidowałby tę właśnie sytuację (komunikacja typu small talk)" (tamże: 57);

- komunikacja autystyczna - „generalnie bazuje na tym, że aktantom zasadniczo obojętne jest, co mówi ten drugi. Interlokutorzy realizują wypowiedzi, nie oglądając się na to, co inni aktanci mogliby z tym począć” (tamże: 61);

- komunikacja eufemistyczna - polega na tym, „by przy pomocy konkretnej wypowiedzi powiedzieć coś konkretnego tak, by w gruncie rzeczy nie zostało to (bezpośrednio) powiedziane, ale zostało przez drugiego aktanta zrozumiane, zaś pierwszy aktant $\mathrm{w}$ każdym momencie miał przekonującą możliwość twierdzenia, że czegoś takiego, co zostało zrozumiane, wcale nie mówił lub by miał możliwość wycofania się z zamanifestowanego stanowiska, znaczenia itp." (tamże: 68);

- komunikacja indeksalna - odmienny typ komunikacji, który pozwala uniknąć wielu problemów, jakie generuje typowa komunikacja prowadzona za pomocą znaków symbolicznych (tamże: 74);

- komunikacja kooperatywna - można ją nazwać komunikacją generatywną - w centrum procesu produkcji wypowiedzi stoi zawsze negocjacja znaczeń, co do których nie panuje jeszcze konsens (tamże: 92);

- komunikacja subwersywna - „bazuje ona, inaczej niż w przypadku komunikacji indeksalnej [...], na demaskacji negocjacji znaczeń, jako działalności opartej na wykorzystaniu stereotypów, uprzedzeń, manipulacji itp.” (tamże: 96).

\section{KomUniKowanie Masowe/MEdiaLne}

Współczesna komunikacja naznaczona jest masowością/medialnością. W opracowaniach często podkreśla się mediatyzację współczesnej komunikacji, a nawet totalną mediatyzację współczesnego świata. Upowszechniło się określenie globalna wioska, którego użył McLuhan na nazwanie świata pomniejszonego do rozmiarów wioski, przez zastosowanie nowych technologii. Goban-Klas (2005: 294) natomiast wprowadził termin spoteczeństwo medialne na określenie „społeczeństwa nasyconego mediami [...]. Jest to społeczeństwo, w którym nie kontakty bezpośrednie [...], ale kontakty zapośredniczone przez media są dominującą formą kontaktów społecznych”.

Komunikowanie masowe/medialne jest jedną z form komunikacji społecznej, która polega na przekazywaniu treści za pomocą mediów, ma zatem charakter pośredni. Francuscy badacze Baylon i Mignot traktują komunikację masową jako: 
zespół zabiegów, poprzez które grupy specjalistów wykorzystują media, aby rozpowszechniać treść informacyjną lub symboliczną. Charakteryzuje się [ta komunikacja] wykorzystaniem najróżniejszych technik (prasy o dużym nakładzie, kina, radia, telewizji, miejskiego plakatu reklamowego itd.), zasięgiem obszaru transmisji (regionalnej, krajowej czy nawet światowej), różnorodnością publiczności, do której dociera (Baylon, Mignot 2008: 177).

Pośredni i jednostronny charakter komunikacji masowej/medialnej powoduje czasowy i przestrzenny dystans między nadawcą i odbiorcą oraz brak wymiany ról między nimi.

Jednak wraz z rozwojem mediów cyfrowych charakter tej komunikacji zmienia się. Media cyfrowe łączą bowiem jednocześnie funkcje komunikowania masowego i interpersonalnego, następuje prywatyzowanie sfery publicznej. Zakres oficjalności komunikacji, np. internetowej, elektronicznej, jest znacznie węższy niż w komunikacji rzeczywistej (realnej) (Grzenia 2006: 64).

$\mathrm{Z}$ komunikacją masową (medialną) wiążą się jeszcze dwie kolejne formy komunikacji społecznej - polityczna i publiczna. Komunikowanie polityczne to "proces transmisji politycznie relewantnych informacji od jednego do pozostałych elementów systemu politycznego, a następnie krążenie tych informacji między systemami - politycznym i społecznym" (Dobek-Ostrowska 2007: 142). Upraszczając, komunikacja polityczna dotyczy relacji między różnymi szczeblami władzy i obywatelami.

Komunikowanie polityczne jest procesem wieloaspektowym; zawiera w sobie elementy i propagandy, i reklamy, i public relations, i wreszcie tzw. marketingu politycznego. Zazwyczaj jest komunikowaniem jednokierunkowym, swoistą transmisją. W systemach otwartych, demokratycznych media, oczywiście, ułatwiają przepływ komunikatów także w przeciwnym kierunku. Kanałem transmisyjnym dla przepływu informacji są - jak wspomniano media. Zwykle komunikowanie polityczne odbywa się w formie wystąpień publicznych tzw. ludzi władzy; są to np. przemówienia, wywiady, konferencje prasowe itp.

Komunikowanie publiczne z kolei ma charakter bardziej sformalizowany (niż polityczne), dotyczy sfery publicznej (nie zaś prywatnej) i ograniczone jest do terytorium regulowanego przez przepisy i prawo. Związane jest z (za)stosowaniem prawa, wprowadzaniem różnorodnych procedur czy podejmowaniem decyzji publicznych. Obejmuje m.in. obowiązek informowania społeczeństwa o sprawach ważnych dla niego - przez prezentację wiadomości w specjalnych serwisach informacyjnych, społecznych kampaniach reklamowych, obejmuje także obowiązek prowadzenia dialogu między nadawcami publicznymi i ich odbiorcami, słuchania uwag i pytań obywateli, składania (tj. podawania do publicznej wiadomości) sprawozdań, a także - pogłębianie 
więzi społecznych, świadomości wspólnotowej na różnych szczeblach życia społecznego. Obejmuje także zapewnienie obywatelom swobodnego dostępu do aktów i dokumentów tworzonych przez administrację publiczną. Jak z powyższego wynika, komunikowanie publiczne bliskie jest komunikowaniu politycznemu i organizacyjnemu. Procesy te zachodzą na siebie swymi zakresami, krzyżują się.

We wszystkich typach komunikacji ważną rolę odgrywa komunikowanie werbalne. Według M. Bugajskiego termin komunikacja to wszelkie interakcje tworzące wspólnotę, a jednym $z$ rodzajów interakcji są interakcje na płaszczyźnie językowej, czyli komunikacja językowa. Dla językoznawcy komunikacja byłaby ustnym lub pisemnym działaniem werbalnym, polegającym na wzajemnym przekazywaniu informacji przez uczestników wspólnoty. Ale szeroko rozumiana komunikacja to także wzory, zasady, normy z wielu różnych innych dziedzin, obowiązujące we wszelkiego rodzaju wspólnotach komunikatywnych (Bugajski 2006: 436, 461). Komunikowanie oznacza bowiem kompleksowe zjawisko - sposób komunikowania się słowem, ale też sposób wykorzystania miejsca, czasu, określonej sytuacji, dyskursów, uwarunkowań osobowościowych itp.

\section{Bibliografia}

Allan S. (2006), Kultura nerwsórw, Kraków.

Antoszewski A., Herbut R. (red.) (2003), Leksykon politologii, Wrocław.

Awdiejew A. (2001), Komunikatywizm (perspektywa metodologiczna badań lingrwistycznych), [w:] G. Habrajska (red.), Język w komunikacji, t. 1, Łódź.

Awdiejew A., Habrajska G. (2010), Komponowanie sensu w procesie odbioru komunikatów, Łódź.

Bańko M. (red.) (2000), Inny stownik jezyka polskiego PWN, Warszawa.

Baran S. J., Davis D. K. (2007), Teorie komunikowania masowego, Kraków.

Bauer Z., Chudziński E. (red.) (2008), Dziennikarstwo i świat mediów, Kraków.

Baylon Ch., Mignot X. (2008), Komunikacja, Kraków.

Bugajski M. (2006), Język w komunikowaniu, Warszawa.

Chudziński E. (red.) (2009), Stownik wiedzy o mediach, wyd. 2, Bielsko-Biała.

Cialdini R. (2012), Wywieranie wplywu na ludzi. Teoria i praktyka, wyd. 6 poszerz., Gdańsk.

Dobek-Ostrowska B. (1999), Studia z teorii komunikowania masowego, Wrocław.

Dobek-Ostrowska B. (2001), Nauka o komunikowaniu. Podstawowe orientacje teoretyczne, Wrocław.

Dobek-Ostrowska B. (2002), Podstawy komunikowania spotecznego, Wrocław.

Dobek-Ostrowska B. (2004), Media masowe i aktorzy polityczni w świetle studiów nad komunikowaniem politycznym, Wrocław.

Dobek-Ostrowska B. (2007), Komunikowanie polityczne i publiczne. Podrecznik akademicki, Warszawa. 
Duszak A. (1998), Tekst, dyskurs, komunikacja międzykulturowa, Warszawa.

Filipiak M. (2003), Homo communicans. Wprowadzenie do teorii masowego komunikowania, Lublin.

Fiske J. (2008), Wprowadzenie do badań nad komunikowaniem, wyd. 2, Wrocław.

Fleischer M. (2002), Teoria kultury i komunikacji, Wrocław.

Fleischer M. (2007), Ogólna teoria komunikacji, Wrocław.

Fleischer M. (2012), Typologia komunikacji, Łódź.

Fras J. (2005), Komunikacja polityczna. Wybrane zagadnienia gatunków i języka wypowiedzi, Wrocław.

Gajda S. (2010), Nowe media w perspektywie lingwistycznej, [w:] B. Bogołębska, M. Worsowicz (red.), Styl-dyskurs - media, Łódź.

Goban-Klas T. (2005), Cywilizacja medialna. Geneza, ewolucja, eksploracja, Warszawa.

Goban-Klas T. (2009), Media i komunikowanie masowe. Teorie i analizy prasy, radia, telewizji i Internetu, Warszawa.

Grabias S. (1994), Jezzyk w zachowaniach spotecznych, Lublin.

Grzenia J. (2006), Komunikacja językowa w Internecie, Warszawa.

Hartley P. (2006), Komunikowanie interpersonalne, Wrocław.

Hopfinger M. (red.) (2005), Nowe media w komunikacji spotecznej w XX wieku. Antologia, wyd. 2. popr., Warszawa.

Jakobson R. (1989), W poszukiwaniu istoty języka: wybór pism, t. 1-2, wybór, red. nauk. i wstęp M. R. Mayenowa, Warszawa.

Kaczmarek B. L. J. (2009), Misterne gry w komunikację, Lublin.

Kita M. (1998), Wywiad prasowy. Jezyk - gatunek - interakcja, Katowice.

Klebaniuk J. (red.) (2005), Psychologiczne konteksty komunikacji, Wrocław.

Komunikacja spoteczna (2003), [w:] A. Antoszewski, R. Herbut (red.), Leksykon politologii, Wrocław.

Kudra B., Kudra A. (2012), O tzw. apodyktycznych figurach konceptualnych w dyskursie politycznym na przyktadzie języka kampanii wyborczej do parlamentu w roku 2011, „Rozprawy Komisji Językowej Łódzkiego Towarzystwa Naukowego”, t. 58, Łódź.

Kulczycki E. (red.) (2012), Komunikologia. Teoria i praktyka komunikacji, Poznań.

McQuail D. (2008), Teoria komunikowania masowego, Warszawa.

Michalczyk S. (2008), Spoteczeństwo medialne. Studia z teorii komunikowania masowego, Katowice.

Michalczyk S. (2012), Teorie mediów w nauce o komunikowaniu, [w:] M. Kita, M. Ślawska (red.), Transdyscyplinarność badań nad komunikacja medialna. Stan wiedzy i postulaty badawcze, t. 1, Katowice.

Mikułowski Pomorski J. (2006), Od mówcy do rozmówcy. Perswazja czy spotkanie? Rewizja klasycznych modeli komunikacji, [w:] M. Gierula, M. Wielopolska-Szymura (red.), Środki masowego komunikowania a spoteczeństwo, Katowice.

Mikułowski Pomorski J. (2012), Jak narody porozumiewaja się ze soba w komunikacji międzykulturowej $i$ komunikowaniu medialnym. Nowa edycja, wyd. 2. uzup., Kraków.

Mikułowski Pomorski J., Nęcki Z. (1983), Komunikowanie skuteczne?, Kraków.

Morin E. (2005), Masowy odbiorca, [w:] M. Hopfinger (red.), Nowe media w komunikacji spotecznej w XX wieku. Antologia, wyd. 2. popr., Warszawa.

Morreale S. P., Spitzberg B. H., Barge K. J. (2008), Komunikacja między ludżmi. Motywacja, wiedza i umiejętności, red. nauk. U. Jakubowska, Warszawa.

Mrozowski M. (2001), Media masowe. Wtadza, rozrywka i biznes, wyd. 2. popr. i uzup., Warszawa. 
Nęcki Z. (1992), Komunikowanie interpersonalne, Wrocław.

Nęcki Z. (1996), Komunikacja międzyludzka, Kraków.

Nęcki Z. (2003), Funkcje komunikacji spotecznej, [w:] K. Wódz, J. Wódz (red.), Funkcje komunikacji spotecznej, Dąbrowa Górnicza.

Nieć M. (2010), Komunikowanie spoteczne i media. Perspektywa politologiczna, Warszawa.

Ogonowska A. (2005), Komunikologia, „Nowa Polszczyzna”, z. 4.

Ong W. J. (1992), Oralność i piśmienność. Stowo poddane technologii, Lublin.

Pisarek W. (2008), Wstep do nauki o komunikowaniu, Warszawa.

Pisarek W. (red.) (2006), Stownik terminologii medialnej, Kraków.

Pratkanis A., Aronson E. (2003), Wiek propagandy. Używanie i nadużywanie perswazji na co dzień, Warszawa.

Rasiński L. (red.) (2009), Język, dyskurs, spoteczeństwo. Zwrot lingwistyczny w flozofii spotecznej, Warszawa.

Skudrzykowa A. (2001), Kontekst indywidualny wobec kontekstu funkcjonalnego-jeszcze o kompetencji interakcyjnej, [w:] G. Habrajska (red.), Język w komunikacji, t. 1, Łódź.

Stankiewicz J. (2006), Komunikowanie się w organizacji, wyd. 3, Wrocław.

Stewart J. (red.) (2007), Mosty zamiast murów. Podręcznik komunikacji interpersonalnej, Warszawa.

Trawkowska D. (2003), Bariery komunikowania przy rozwiqzzywaniu problemów spotecznych - na podstawie badań empirycznych w instytucjach pomocy spotecznej, [w:] K. Wódz, J. Wódz (red.), Funkcje komunikacji spotecznej, Dąbrowa Górnicza.

Wódz K., Wódz J. (red.) (2003), Funkcje komunikacji spotecznej, Dąbrowa Górnicza. Żydek-Bednarczuk U. (2005), Wprowadzenie do lingwistycznej analizy tekstu, Kraków. 